\title{
Fostering Inclusive Teaching: A Systemic Approach to Develop Faculty Competencies
}

\author{
Diane Ceo-DiFrancesco \\ Xavier University \\ Mary K. Kochlefl \\ Xavier University \\ Janice Walker \\ Xavier University
}

Motivated by climate survey findings and racial bias incidents on a Midwestern, Jesuit, Catholic university campus, the Institutional Diversity and Inclusion Office and Center for Teaching Excellence began a journey to strengthen faculty competencies related to inclusive teaching. This case study provides background on the need for training, an overview of the Diversity and Inclusive Teaching Academy developed, challenges presented during planning and implementation processes, and implications for faculty development. Evaluation results demonstrate the importance of modeling sound pedagogical practices, providing challenging and demanding content that stretches understanding of key issues, and fostering interdisciplinary communities of learners in supportive environments.

\section{INTRODUCTION}

The university student population is rapidly changing across the United States, a factor that presents an increasingly diverse group of students in today's classrooms. Enrollment rates for students of color have increased in colleges and universities, while the largest racial minority group in the United States, Latinos/Hispanics, doubled between the years 2000 and 2016 (National Center for Educational Statistics, 2018). In fall 2016, female undergraduates students made up $56 \%$ of the total undergraduate enrollment (National Center for Educational Statistics, 2018), and non-traditional adult student enrollment is on the rise (Bowl \& Bathmaker, 2016). In addition, students who identify their gender preferences as LGBTQ+search for supportive university learning experiences (Garvey \& Rankin, 2015).

This increasingly diverse group of students brings to the classroom equally diverse racial, gender, ethnic, cultural and linguistic backgrounds. Seemiller and Grace (2017) describe the latest generation of students, Generation Z, as a group of students concerned about racism and social justice issues. Yet the diversity of higher education educators is disproportionately lower than the students whom they encounter in their classrooms (Li \&Koebdel, 2017), and their potential lack of training on cultural norms and differences and inclusive teaching practices may compound the issue. According to hooks (1994), most faculty learn to teach through exposure to the teaching styles of their own teachers. These models, 
however, have often trained educators in a singular norm which is unconsciously duplicated. Although well intentioned, faculty can reinforce particular perspectives and practices of privileged populations unless they strive to make deliberate adjustments to the norms ingrained in them during their own years as learners.

Faculty training in diversity and inclusive teaching practices continues to be a focus of centers for teaching excellence on university campuses, documented by those working in the field of faculty development (Booker, Merriweather, \& Campbell-Whatley, 2016; Chavez \& Longerbeam, 2016; Considine, Mihalick, Mogi-Hein, Penick-Parks, \& Van Auken, 2014; Lawrie et al., 2017). A move from teacher-centered to learner-centered education (Weimer, M. E., 2013; Nilson, 2017),pressures to increase retention and graduation rates (Selingo, 2015; Felten, Gardner, Schroeder, Lambert, \& Barefoot, 2016), and research regarding students' sense of belonging (Ambrose, Bridges, DiPietro, Lovett, \& Norman, 2010; Strayhorn, 2012)add additional impetus to the growing demand for adjustments to classroom practices on college campuses. Finally, Hocking (2010) calls for an institutional approach to inclusive practices to more effectively encourage needed change.

Recent racial bias incidents and students' call for immediate action, along with administrators' responses, resulted in pressures for faculty with varying levels of background and training to respond appropriately in the classroom by becoming more culturally competent and enacting inclusive teaching practices. The current study presents an overview of a diversity and inclusion training program at one Midwestern, Jesuit, Catholic university in the form of a case study. This work attempts to answer the following questions:

1. To what extent and in what ways can diversity education and inclusive teacher training meet the demands of a wide range of stakeholders?

2. What implications for future training are evident based on the implementation process reported in this case study?

\section{BACKGROUND}

The creation of the academy was prompted by both planned institutional processes and unanticipated campus events. Having created a chief institutional diversity and inclusion officer (CDIO) position, the university undertook a campus climate survey in spring 2016. In October 2016, as the new CDIO took office, survey results were shared, with key findings suggesting that underrepresented student groups (students of color, LGBTQ + students, first generation students, etc.) experienced the campus climate both inside and outside of the classroom less positively than their majority identity peers. Results relevant to this finding include notable differences among constituent groups of students around whether they felt valued and respected by faculty, or prejudged by faculty, whether they considered leaving the university, and whether they felt difficult topics were welcomed in the classroom. While the campus climate survey results were not atypical for a majority white, private university, they did provide data on and sparked conversations about the wide variations among students' perceptions and experiences. Given the institutional mission of fostering a caring community that respects the dignity of every individual and supporting all students as they cultivate lives of reflection, compassion and informed action, the survey results were troubling.

Just as the campus climate survey results were being released, the new CDIO came on board and assumed the duties and responsibilities of the position. To support and advise her, the university established a diversity and inclusion action and advisory council, a broad representation of comprised of faculty, staff and students from across the campus. Prior to the CDIO's arrival, the council made a primary focus for their work the understanding of the complexity of diversity and inclusion issues in anticipation of supporting the development of the university's diversity and inclusion strategic plan.

Two weeks after the arrival of the CDIO and release of the campus climate findings, two student incidents occurred that called attention to racial issues on campus: A student posted a photo of herself in black face on social media with the caption "Who needs white when black lives matter?"; and, two days later it was followed by a photo taken of a skeleton wearing a dashiki hanging from the ceiling in a dorm 
room, also shared on social media. Following university's bias incident protocol, an open forum was organized to discuss the racial bias incidents. Unprecedented concern and interest were expressed. Approximately 800 students, alumni, faculty and staff turned out for the forum, which became discussions facilitated in multiple rooms throughout the student center building. Many students of color came forward during the discussions to share very moving personal experiences of racial bias, making clear the incidents setting in motion the forum were neither isolated nor inconsequential.

The campus climate was further strained by the 2016 presidential election soon thereafter in early November, which left not only people of color and women feeling even less secure in the country and on the campus, but also international students, people of different faith traditions, and LGBTQ+ groups. Some majority students felt empowered to express views that would not have been acceptable or tolerated before the election. While the disconnect between the student and faculty experience in many cases seemed to enlarge, the need for faculty to be able to facilitate difficult dialogues among their students also grew. Acknowledging the various reactions (e.g. pain, depression, shock and/or anger) of many students to the election became more complicated as the naming of students as "snowflakes" became prevalent in the public discourse.

\section{DEVELOPMENT OF THE DIVERSITY AND INCLUSION TEACHING ACADEMY}

Within months of the arrival of the CDIO, the five-year strategic plan, shaped through this process and subsequent campus events, took shape, focused on six broad goals, one of which was to "promote diversity education, scholarship and culturally responsive teaching." An objective within this goal focused on enhancing the cultural competency of faculty and staff. A strategy for achieving this objective named the faculty training being designed: "Create an inclusive teaching academy to provide an extensive series of modules for developing key diversity competencies (e.g. awareness of self/privilege), implementing inclusive teaching strategies, and facilitating difficult but crucial conversations (e.g. race) in the learning environment" (Walker, 2018).

These several factors, particularly the racial bias incidents on campus, led to various stakeholders voicing the need for an institutional response. According to Watt (2016), these types of conditions often create a "perfect storm"on university campuses, with multiple layers of the institution focused on "the need to engage Difference effectively..." (Watt, 2016, p. 2).At Xavier, students asked for immediate and visible changes, including that faculty be better trained to make classroom environments more inclusive. The university president and trustees turned to the CDIO and Center for Teaching Excellence to provide support with faculty development. The center had previously received funding from the president for diversity-specific programming, and had followed the campus incidents by convening faculty to discuss how they responded in the classroom. Training options considered by upper administration included purchased online solutions, which could be implemented quickly, in a standardized format accessible to all, and would provide easy accountability for completion.

As a stakeholder, the Center for Teaching Excellence proposed developing a blended training in house, comprised of modules focused on key pedagogical competencies and facilitated in small cohorts by faculty peers. For greater impact, reflection and introspection were proposed to accompany content that prioritized teaching strategies. University data and subject matter experts would be used to convey relevance and local context. Responsible for faculty development across the university, the center considered how the training could be scaled, including to adjunct faculty who are physically present on campus only infrequently.

Additional stakeholders included faculty with expertise and investment in diversity issues. These faculty brought concerns that a superficial training might provide a false sense of expertise and lack of appreciation for the actual complexity of diversity studies, which could potentially do more harm than good when applied in the classroom. Furthermore, they argued it would take significant time to curate the appropriate content and even longer to effect real change in faculty attitudes and practices. While they agreed there was no quick solution, some of the faculty diversity experts advocated for the standard, 
purchased training to ensure consistency of experience and lead to common foundational knowledge and vocabulary.

Additional stakeholders included deans and department chairs who voiced concerns about adding to faculty workload. Questions were raised about whether the training would be mandatory, what the time commitment would be, and if faculty would be compensated or otherwise recognized for participating. Beyond pay, options for incentives included issuing certifications of completion, building diversity expectations into the annual review process, and listing participants during the annual Faculty Recognition reception. Concerned about faculty time, some stakeholders proposed solutions that focused on immediate classroom opportunities to enact inclusive strategies - such as a list of quick tips for how instructors could respond to a diversity-related conflict or micro aggressions.

By providing a voice to marginalized individuals and respecting historical contexts, navigation of various interest groups took place through multiple conversations, with the CDIO acting as a "conscious scholar practitioner" (Watt, 2016), and balancing dialogue with decisions (Watt, 2011). However pressure continued for visible and swift action, accountable to requests from students and trustees. By the middle of the spring 2017 semester, a blended course was tentatively outlined with broad learning outcomes. Three faculty were enlisted to assist the Center for Teaching Excellence directors and CDIO in determining specific content and assignments over the summer, with a fall pilot planned.

The version of the Diversity and Inclusion Teaching Academy that launched as a pilot in September 2017 consisted of three large modules, divided into weekly sub-modules that spanned 14 weeks. Three learning outcomes guided the modules:

By the end of the Diversity and Inclusion Teaching Academy, participants will be able to:

1. Identify your own cultural framework and its effects on teaching and learning

2. Articulate a plan for fostering greater inclusivity in your teaching

3. Facilitate students in critical dialogue related to diversity and inclusion

The sub-modules addressed the following topics:

Module 1: Self-Reflection

- Module 1a - The Jesuit Tradition and Diversity

- Module $1 \mathrm{~b}$ - Cultural Identities of Instructors

- Module 1c - Part One - Implicit Bias

- Module 1c - Part Two - Microaggressions and Stereotype Threat

- Module 1d - Part One - Students' Cultural Identities

- Module 1d - Part Two - Privilege

- Module 1e - Impacts of Mental Health

- Module 1f - Bias Against Instructors

Module 2: Strategies for Fostering Inclusivity

- Module 2a - Belonging

- Module 2b - Instructor Strategies

- Module 2c-Community Building

- Module 2d - Course Content

Module 3: Critical Dialogue

- Module 3a - Opportunities for Critical Dialogue

- Module 3b - Facilitating Critical Dialogue

Each sub-module consisted of content, including articles and book chapters, videos, narrated interpretations of climate survey data, and relevant internal documents. Videos in two sub-modules, on implicit bias and mental health, were narrated by faculty members. A section at the end of each submodule, titled "Optional Resources," provided additional content. Each sub-module included a discussion; in this initial pilot offering, three of these took place in person, while the remaining 11 were online discussion boards. Guest faculty and staff facilitators led or joined several of the discussions. Module 1 included a Culture and Teaching Autobiography assignment (Longerbeam \& Chavez, 2016), issued in five segments, which focused on self-reflection. Module 2 included an Inclusive Teaching Plan, comprised of four inventories of participants' teaching practices, related to the sub-module topics, and an 
opportunity to indicate goals for enhancing strategies to be more inclusive. A final, optional assignment was offered at the end of each sub-module: a Daily Examen of Consciousness for Diversity. Developed at the university as an extension of the Jesuit tradition of a Daily Examen (Mooney \& Muñoz, n.d.), the Diversity Examen is a set of introspective prompts related to the day's experiences of one's own culture and the culture of others.

Participants for the initial pilot were invited by the CDIO, from faculty with known expertise in diversity and inclusion and those with strong interest in inclusive pedagogies. Two cohorts were formed, each with 13 participants and one facilitator. Three participants were faculty who had moved into administrative roles; two participants were staff in the Center for Diversity and Inclusion. Over the semester, three participants formally dropped out due to other time commitments. Remaining participants maintained an active role unevenly, with many not persisting through the final weeks. Faculty were not compensated, with the exception of the facilitators.

Through brief surveys at the mid-point and end of the semester, as well as focus groups after the Academy concluded, the following feedback informed modifications for the second pilot offering:

- 14 weeks was too long, given competing demands and the ramping up of grading and advising responsibilities during the second half of the semester

- Module content and assignments were too extensive; in particular, the Culture and Teaching Autobiography was not being completed due to time constraints

- Some content was addressed too simplistically, especially considerations of the complexity of cultural identity, issues of structural oppression, and the Society of Jesus' historical relationship to inclusivity

- In-person discussions were found more valuable and time-efficient; thoughtful, but lengthy, online posts set an expectation for equally lengthy responses

- While some participants engaged the modules with personal and introspective reflection, others were more comfortable with more academic responses, which led to unfulfilled expectations on both sides; as a corollary, some faculty expressed concerns about confidentiality and being open, especially given the mix of faculty and administrators among participants

For the second pilot offering, in spring 2018, modifications addressed this input. The most significant change was splitting the academy into two parts, each of which would last approximately eight weeks during the first half of the semesters (Semester One if spring 2018 and Semester Two in fall 2018). Significantly, the order of module topics was adjusted, with greater consideration given to issues of power and structural oppression as foundational concepts (Black \& Stone, 2005) before inclusive teaching strategies were addressed. More diverse voices and genres were added to the module content. Additional faculty members with diversity expertise participated in the revisions, especially for the Semester One modules. New overarching learning outcomes oriented the two parts:

By the end of the Diversity \& Inclusion Teaching Academy, you will be able to:

- Semester One: Examine how structures and lived experiences influence faculty's ability to effectively teach a diverse student body.

- Semester Two: Having reflected on your own cultural framework and its impact on your teaching practices, articulate strategies for fostering greater inclusivity in your teaching

While some sub-modules remained largely intact, others were significantly revised along with the reordering of topics:

Semester One Topics:

- Module 1 (two parts): Structural frameworks that create and maintain disenfranchised populations

- Module 2: Privilege

- Module 3:The Jesuit tradition and diversity

- Module 4(two parts):

- Module 4a: Implicit bias 
- Module 4b: Micro aggressions and stereotype threat

- Module 5(two parts):

- Module 5a: Power and privilege in the classroom

- Module 5b: Bias toward and against instructors

Semester Two Topics:

- Module 1: Teaching across cultures

- Module 2:Teaching inclusively

- Module 2a: Student belonging

- Module 2b: Student interaction

- Module 2c: Course content and syllabus design

- Module 3: Impacts of mental health

- Module 4: Facilitating critical dialogue

- Module 4a: Productive dialogue on diversity-related topics

- Module 4b: Triggering situations

Revisions for the second pilot included changes to assignments. The number of in-person discussions was increased to five in Semester One and four in Semester Two. An initial in-person session was added to each part to facilitate community norm setting regarding confidentiality and expectations for participation. Online discussion prompts were reframed to provide both academic and introspective options. While more intentional self-reflection was moved into Semester Two, along with a concentrated focus on teaching strategies, the Culture and Teaching Autobiography assignment was eliminated.

Recruiting for the second pilot offerings started with nominations from the deans, followed by invitations from the CDIO. Separate cohorts were established for administrators (associate deans and department chairs) to account for power dynamics. In spring 2018, two cohorts of faculty and one cohort of administrators participated in the Semester One course; 37 participants in total started, with seven withdrawing due to time constraints. In fall 2018, two cohorts of faculty and one cohort of administrators participated in Semester One, for a total of 42, with six withdrawing. One cohort of 14 faculty started Semester Two, and 13 of these completed. Over the three semesters, a total of 93 faculty and administrators have participated, including six facilitators; of these, 37 have completed either the full semester version or both semesters. While more than half of the participants are from the College of Arts and Sciences, which has the largest number of full-time faculty, the remaining half is divided evenly between the university's other two colleges, the College of Professional Sciences and the Williams College of Business.

\section{EVALUATION}

The researchers administered a post-treatment survey to faculty and administrator participants at the final in-person session of the academy for the spring 2018 and fall 2018 semesters. Participants responded to statements utilizing a five point Likert scale to self-rate their growth and understanding of diversity and inclusion and to rate the effectiveness of the various resource elements included in the modules. (See Appendix A for survey instrument.) Results of survey demonstrated a greater awareness of understanding and awareness regarding the diversity and inclusion content of Semester One of the academy. For instance, $92 \%$ of participants agreed or strongly agreed that their ability to effectively teach a diverse student body had been enhanced based of their participation in the academy. 100\% believed that their understanding of structural bases of inequity had been strengthened, and $98 \%$ agreed that they had a greater understanding of power and privilege and its role in the learning environment.

Regarding participants' increased abilities to address diversity and inclusion matters in their classrooms, $96 \%$ of participants believed that they had gained a greater understanding of the ways in which bias impacts teaching and learning. The same percentage rated themselves as better prepared to address micro aggressions in the classroom, while $82 \%$ felt more comfortable promoting critical dialogue related to diversity and inclusion in the classroom. $98 \%$ of participants believed that overall their 
knowledge of inclusivity and diversity in the classroom had been strengthened due to their participation in the academy.

Although Semester One of the academy did not specifically address teaching strategies and practices, $88 \%$ of participants agreed or strongly agreed that the academy had provided them with strategies for addressing inequity in the classroom. Finally, $100 \%$ agreed or strongly agreed that the academy was worth the time and effort they had invested. See Table 1 for faculty ratings upon completion of Semester One of the Diversity and Inclusion Teaching Academy.

\section{TABLE 1}

SURVEY RESULTS SEMESTER ONE - SPRING 2018 AND FALL 2018 (N=52)

\begin{tabular}{|l|c|}
\hline After completing the Diversity and Inclusion Teaching Academy: & $\begin{array}{c}\text { Strongly agree or } \\
\text { Somewhat agree }\end{array}$ \\
\hline My ability to effectively teach a diverse student body has been enhanced. & $92 \%$ \\
\hline My understanding of the structural bases of inequality has been strengthened. & $100 \%$ \\
\hline $\begin{array}{l}\text { I have a greater understanding of privilege and the role it plays in the learning } \\
\text { environment. }\end{array}$ & $98 \%$ \\
\hline $\begin{array}{l}\text { My understanding of Xavier's mission related to diversity and inclusion has } \\
\text { grown. }\end{array}$ & $88 \%$ \\
\hline $\begin{array}{l}\text { I have gained a greater understanding of the ways in which bias impacts teaching } \\
\text { and learning. }\end{array}$ & $96 \%$ \\
\hline $\begin{array}{l}\text { My understanding of the dynamics of power and privilege within the classroom } \\
\text { has grown. }\end{array}$ & $96 \%$ \\
\hline I am better prepared to address micro aggressions in the classroom. & $91 \%$ \\
\hline The reading represented diverse perspectives. & $94 \%$ \\
\hline The amount of reading was reasonable. & $88 \%$ \\
\hline The time required to complete the Academy was reasonable. & $86 \%$ \\
\hline The variety of materials was useful. & $94 \%$ \\
\hline Discussion board topics were engaging. & $71 \%$ \\
\hline $\begin{array}{l}\text { The Diversity and Inclusion Teaching Academy challenged my previously held } \\
\text { assumptions about inclusivity and diversity in the classroom. }\end{array}$ & $98 \%$ \\
\hline $\begin{array}{l}\text { Overall the Diversity and Inclusion Teaching Academy strengthened my } \\
\text { knowledge about inclusivity and diversity in the classroom. }\end{array}$ & $88 \%$ \\
\hline $\begin{array}{l}\text { The Diversity and Inclusion Teaching Academy has provided me with specific } \\
\text { strategies for addressing inequity in the classroom. }\end{array}$ & $100 \%$ \\
\hline $\begin{array}{l}\text { Overall the Diversity and Inclusion Teaching Academy has been worth the time } \\
\text { and effort I have invested. }\end{array}$ & \\
\hline
\end{tabular}

Two themes pertaining to strengths of the program emerged from the analysis of the qualitative comments from Semester One of the academy. First, faculty emphasized their appreciation for the opportunities to meet face to face with colleagues from across the university. As one faculty member wrote that, "Bringing faculty from diverse areas to share experience and knowledge," was a definite strength. Similarly, another faculty member pointed to community as a positive aspect: "Having space to discuss issues that we might be nervous bringing up elsewhere." From the chair and administrator group, one member mentioned, "Liked cohort model (all chairs and administrators), collegiality of peers." The second theme was an emphasis on engaging content. Participants cited specific readings, videos, guest speakers and additional resources, in particular those pertaining to implicit bias and micro aggressions, as "very thought provoking," "revealing," and "valuable."

When asked about action steps participants plan to apply to their classroom teaching based on their learning from the academy, themes emerged including being more attentive to diversity of content, being 
mindful of actions and bias, and increasing dialogue. For instance, one participant wrote, "I am even more mindful about my readings and my use of language." Participants cited plans to be more mindful of their words and actions, particularly those pertaining to micro aggressions and bias. Regarding increasing dialogue, a participant shared intentions to "address bias incidents in the classroom when they are significant on campus," and another mentioned plans to "be braver about stopping micro aggressions."

The results from the first implementation of Semester Two of the academy also yielded positive results. $100 \%$ of the participants strongly agreed or agreed with nearly all of the question items, with the exception of a rating of neutral for the following items: level of comfort with conducting difficult dialogues, challenge to previous assumptions, the time required for participation and the variety of materials. Two participants rated the discussion boards as a less favorite form of interaction. See Table 2 for second semester results.

TABLE 2

\section{SURVEY RESULTS SEMESTER TWO -FALL 2018 (N=8)}

\begin{tabular}{|l|c|}
\hline After completing the Diversity and Inclusion Teaching Academy: & $\begin{array}{c}\text { Strongly agree or } \\
\text { Somewhat agree }\end{array}$ \\
\hline My ability to effectively teach a diverse student body has been enhanced. & $100 \%$ \\
\hline My understanding of the structural bases of inequality has been strengthened. & $100 \%$ \\
\hline $\begin{array}{l}\text { I have a greater understanding of privilege and the role it plays in the learning } \\
\text { environment. }\end{array}$ & $100 \%$ \\
\hline $\begin{array}{l}\text { My understanding of Xavier's mission related to diversity and inclusion has } \\
\text { grown. }\end{array}$ & $87 \%$ \\
\hline $\begin{array}{l}\text { I have gained a greater understanding of the ways in which bias impacts teaching } \\
\text { and learning. }\end{array}$ & $100 \%$ \\
\hline $\begin{array}{l}\text { My understanding of the dynamics of power and privilege within the classroom } \\
\text { has grown. }\end{array}$ & $100 \%$ \\
\hline I am better prepared to address micro aggressions in the classroom. \\
\hline The reading represented diverse perspectives. & $100 \%$ \\
\hline The amount of reading was reasonable. & $87 \%$ \\
\hline The time required to complete the Academy was reasonable. & $75 \%$ \\
\hline The variety of materials was useful. & $87 \%$ \\
\hline Discussion board topics were engaging. & $75 \%$ \\
\hline $\begin{array}{l}\text { The Diversity and Inclusion Teaching Academy challenged my previously held } \\
\text { assumptions about inclusivity and diversity in the classroom. }\end{array}$ & $87 \%$ \\
\hline $\begin{array}{l}\text { Overall the Diversity and Inclusion Teaching Academy strengthened my } \\
\text { knowledge about inclusivity and diversity in the classroom. }\end{array}$ & $100 \%$ \\
\hline $\begin{array}{l}\text { The Diversity and Inclusion Teaching Academy has provided me with specific } \\
\text { strategies for addressing inequity in the classroom. }\end{array}$ & $100 \%$ \\
\hline $\begin{array}{l}\text { Overall the Diversity and Inclusion Teaching Academy has been worth the time } \\
\text { and effort I have invested. }\end{array}$ & $100 \%$ \\
\hline
\end{tabular}

Qualitative comments regarding strengths of the academy after the second semester of participation mirrored the results from the first semester, with the themes of community and content clearly emerging from the analysis. However, plans for application to the classroom focused more on the themes of applying specific strategies and techniques and facilitating difficult dialogues and discussions. One participant cited plans to "incorporate developing guidelines for group work and discussions," and another described the effect of the academy on teaching, "I am more intentional and more comfortable in my classroom now dealing with diverse students and conversations about diversity issues, which means 
that more of these conversations happen and that they go deeper than they would if I felt out of my depth."

\section{DISCUSSION}

Following the feedback of participants from the 14-week pilot academy, the creators of the academy came to understand that faculty sought opportunities for complex readings and resources that promoted participation in critical dialogue and reflection. Although the complexity and critical pedagogy prompted faculty to reexamine beliefs and perspectives, resulting in a level of dissonance and discomfort, it is precisely this discomfort that can lead to transformative learning (Cranton, 2016; Donaday, 2002; Festinger, 1957; Mezirow, 1991). According to Mezirow (2003), as adult learners question and challenge their hidden assumptions they begin to grow in their understanding of a given topic or context. Due to the transformative learning potential of the program, dividing the academy into two parts over two semesters is appropriate.

Facilitators came to realize the importance of modeling inclusivity strategies as part of the academy experience, particularly due to the fact that faculty tend to rely on their own experiences as learners to inform their teaching (hooks, 1994; Mayhew \& Fernández, 2007). By calling attention to the power dynamics that exist among any group of faculty, facilitators encouraged community norm setting to provide a safe space for faculty to participate in online and in-person discussions without feeling a need to withhold the sharing of experiences. Building ally-ship among community members allowed for faculty growth during the learning experience, but also encouraged alliances across disciplines and colleges. According to Mezirow (1991) the discourse, dialogue and support from others creates a learning environment that is conducive to transformative learning. The support and scaffolding provided to learners is crucial and building a sense of community among the faculty member learners is critical to their learning experience (Anderson, 1994). Providing differentiated learning opportunities, including multiple levels of readiness, allowed all faculty to feel a sense of belonging and safety as they began their participation in the academy. Finally, facilitators modeled how to acknowledge missteps during in-person and online discussions in the context of the real situations in which the missteps occurred.

\section{IMPLICATIONS FOR FACULTY DEVELOPMENT}

Implementation of the diversity and inclusion teaching academy raised several key points for faculty development. First, facilitators, creators and administrators of the program recognized the importance of modeling sound pedagogical practices, specifically those related to alternative and critical pedagogy that call into question the power dynamics and epistemic injustices that exist within the classroom and beyond (Freire, 1970; hooks, 1994; Pope \& Reynolds, 1997). These practices include the transmission of content in multiple ways, including reading, viewing, active learning tasks, online and in-person discussions and critical reflection, as well as the application of pedagogical techniques that benefit all learners (Anderson, 1994). Such practices enhance faculty grasp of concepts and provide appropriate models of techniques that they experience through the lens of learners.

Faced with a learning opportunity that will enhance their teaching and potentially make a difference among their students, faculty take this learning seriously, to the extent to which they request demanding content to stretch their understanding of key issues. Training programs in diversity and inclusive teaching practices, therefore, must honor the intellectual curiosity and high expectations of faculty participants. Faculty were interested not only in the issues of diversity and inclusion as they related to students in the classroom, but many also longed to discuss and share personal experiences and issues with implicit bias, power and privilege with colleagues and peers in their own departments as well as across the university.

The levels of positive faculty responses to participate in the diversity and inclusion academy demonstrate the importance of connecting their investment in this work to an institutional agenda with support from a variety of stakeholders across campus. Anderson (2008) suggests a shift from one-off workshops to more long-term investments that encourage faculty collaborations across the university. In 
addition, while tapping into intrinsic motivation may be successful to some extent, particularly with faculty already interested in a topic, many faculty seek opportunities for greater recognition and rewards. Creating a system of recognition, from certificates of completion, letters to the deans to acknowledge faculty participation, to inclusion of completion on a faculty member's annual review, such practices supply the extrinsic motivation that strengthens the intellectual community of the university and enhances the students' learning experiences in the classroom.

\section{CONCLUSION}

Navigating stakeholder interests enabled a rich conversation that resulted in a successful inclusive pedagogical training model. Driven by an urgency to develop an immediate solution, the training kept in mind goals of enhancing learning of diverse range of students and developing deep and lasting faculty competencies. Evaluation results of the two-part training held during two semesters, designed with faculty input and created utilizing faculty and staff expertise, are positive. Participants appreciated the organizational structure of cohorts, wherein learning takes place in a safe environment and participants are comfortable sharing their successes and their insecurities with a community of learners from across disciplines and colleges. Impactful training includes in-depth resources that challenges participants to reexamine assumptions and biases. Rather than ensuring participation through administrative enforcement, faculty accept an invitation to engage deeply with quality content and the promise of an interactive, supportive community.

\section{REFERENCES}

Ambrose, S., Bridges, M.W., DiPietro, M., Lovett, M.C., \& Norman, M.K. (2010). How learning works: Seven research-based principles for smart teaching. San Francisco: Jossey-Bass.

Anderson, J. A. (1994). Examining teaching styles and student learning styles in science and math classrooms. In M. M. Atwater (Ed.), Multicultural education: Inclusion of all (pp. 93-106). Athens: University of Georgia Press.

Anderson, J.A. (2008). Driving change through diversity and globalization: Transformative leadership in the academy. Sterling, VA: Stylus.

Black, L.L., \& Stone, D. (2005). Expanding the definition of privilege: The Concept of social privilege. Journal of Multicultural Counseling and Development, 33(4), 243-255.

Booker, K. C., Merriweather, L., Campbell-Whatley, G. (2016). The Effects of diversity training on faculty and students' classroom experiences. International Journal for the Scholarship of Teaching and Learning, 10, (1), Article 3. DOI https://doi.org/10.20429/ijsotl.2016.100103.

Bowl, M. \&Bathmaker, A. (2016). Non-traditional students and diversity in higher education. In J. E. Cote' \& A. Furlong (Eds.) Handbook of sociology of higher education, (pp. 142-152). New York: Routledge.

Chavez, A. F. \&Longerbeam, S. D. (2016). Teaching across cultural strengths: A Guide to balancing integrated and individuated cultural frameworks in college teaching. Sterling, VA: Stylus.

Considine, J. R., Mihalick, J. E., Mogi-Hein, Y. R., Penick-Parks, M. W., \& Van Auken, P. M. (2014). 'Who am I to bring diversity into the classroom?' Learning communities wrestle with creating inclusive college classrooms. Journal of the Scholarship of Teaching and Learning, 14(4), 18-30.

Cranton, P. (1996). Professional development as transformative learning: New perspectives for teachers of adults. San Francisco: Jossey-Bass.

Donaday, A. (2002). Negotiating tensions: Teaching about race issues in graduate feminist classrooms. NWSA Journal, 14(1), 82-102.

Felten, P., Gardner, J. N., Schroeder, C. C., Lambert, L. M., \& Barefoot, B. (2016). The Undergraduate experience: Focusing institutions on what matters most. San Francisco: Jossey-Bass.

Festinger, L. (1957). A Theory of cognitive dissonance. Palo Alto, CA: Stanford University Press.

Freire, P. (1970). Pedagogy of the oppressed. New Yok: Continuum. 
Garvey, J. C. \& Rankin, S. R. (2015). Making the grade? Classroom climate for LGBTQ students across gender conformity. Journal of Student Affairs Research \& Practice, 52(2), 190-203.

Hockings, C. (2010). Inclusive learning and teaching in higher education: A synthesis of research. York: Higher Education Academy. Retrieved October 21, 2018, from EvidenceNet Website: https://www.heacademy.ac.uk/system/files/inclusive_teaching_and_learning_in_he_synthesis_20 0410_0.pdf

Hooks, Bell (1994). Teaching to transgress: Education as the practice of freedom. New York: Routledge.

Lawrie, G., Marquis, E., Fuller, E., Newman, T., Qiu, M., Nomikoudis, M.,...van Dam, L. (2017). Moving towards inclusive learning and teaching: A synthesis of recent literature. Teaching \& Learning Inquiry, 5, (1), 10. DOI: https://doi.org/10.20343/teachlearninqu.5.1.3

$\mathrm{Li}, \mathrm{D}$. \&Koedel, C. Representation and salary gaps by race-ethnicity and gender at selective public universities. Educational researcher, 46(7), 343-354.

Longerbeam, S. D. \& Chavez, A. F. (2016). Going inward: The Role of cultural introspection in college teaching. New York: Peter Lang.

Mayew, M. J. \& Fernández, S. D. (2007). Pedagogical practices that contribute to social justice outcomes. The Review of Higher Education 31(1), 55-80.

Mezirow, J. (1991). Transformative dimensions of adult learning. San Francisco: Jossey-Bass.

Mezirow, J. (2003). Transformative learning as discourse. Journal of Transformative Education, 1(1), 5863.

Mooney, D. \& Muñoz, C. (n.d.) The Diversity Examen. Retrieved October 21, 2018, from Xavier University Web Site: https://www.xavier.edu/jesuitresource/jesuit-a-z/terms-e/index

National Center for Education Statistics. (2018). The Condition of Education. Retrieved October 21, 2018, from National Center for Education Statistics: https://nces.ed.gov/programs/coe/indicator_cha.asp

Pope, R. L. \& Reynolds, A. L. (1997). Student affairs core competencies: Integrating multicultural awareness, knowledge, and skills. Journal of College Student Development, 38(3), 266-277.

Nilson, L. (2016). Teaching at its best: A Research-based resource for college instructors. San Francisco: Jossey-Bass.

Selingo, J. J. (2015). College (un)bound: The Future of higher education and what it means for students. Las Vegas: Amazon.

Strayhorn, T. L. (2012). College students' sense of belonging: A Key to educational success for all students. New York: Routledge.

Walker, J. (2018). Diversity and inclusion strategic plan. Retrieved October 21, 2018, from Xavier University website: https://www.xavier.edu/institutional-diversity inclusion/documents/DiversityandInclusionStrategicPlanFinal.pdf

Watt, S. K. (2011). Moving beyond the talk: From difficult dialogues to action. In J. Arminio\& V. Torres (Eds.), Why aren't we there yet? Taking personal responsibility for creating an inclusive campus (pp. 131-144),Sterling, VA: Stylus.

Watt, S. K. (2016). Designing transformative multicultural Initiatives: Theoretical foundations, practical applications, and facilitator considerations. Sterling, VA: Stylus.

Weimer, M. (2013). Learner-Centered teaching: Five key changes to practice. San Francisco: JosseyBass. 


\section{APPENDIX A}

\section{Diversity and Inclusion Teaching Academy Feedback}

Please respond to the questions below. We greatly value your feedback as we continue to improve the Diversity and Inclusion Teaching Academy. Please check the appropriate box:

\begin{tabular}{|l|l|l|l|l|l|}
\hline $\begin{array}{l}\text { After completing the Diversity and } \\
\text { Inclusion Teaching Academy: }\end{array}$ & $\begin{array}{c}\text { Strongly } \\
\text { agree }\end{array}$ & $\begin{array}{c}\text { Somewhat } \\
\text { agree }\end{array}$ & $\begin{array}{c}\text { Neither } \\
\text { agree } \\
\text { nor } \\
\text { disagree }\end{array}$ & $\begin{array}{c}\text { Somewhat } \\
\text { disagree }\end{array}$ & $\begin{array}{c}\text { Strongly } \\
\text { disagree }\end{array}$ \\
\hline $\begin{array}{l}\text { My ability to effectively teach a diverse } \\
\text { student body has been enhanced. }\end{array}$ & & & & & \\
\hline $\begin{array}{l}\text { My understanding of the structural bases } \\
\text { of inequality has been strengthened. }\end{array}$ & & & & & \\
\hline $\begin{array}{l}\text { I have a greater understanding of privilege } \\
\text { and the role it plays in the learning } \\
\text { environment. }\end{array}$ & & & & & \\
\hline $\begin{array}{l}\text { My understanding of Xavier's mission } \\
\text { related to diversity and inclusion has } \\
\text { grown. }\end{array}$ & & & & & \\
\hline $\begin{array}{l}\text { I have gained a greater understanding of } \\
\text { the ways in which bias impacts teaching } \\
\text { and learning. }\end{array}$ & & & & & \\
\hline $\begin{array}{l}\text { My understanding of the dynamics of } \\
\text { power and privilege within the classroom } \\
\text { has grown. }\end{array}$ & & & & & \\
\hline $\begin{array}{l}\text { I am better prepared to address micro } \\
\text { aggressions in the classroom. }\end{array}$ & & & & & \\
\hline $\begin{array}{l}\text { I feel more comfortable promoting critical } \\
\text { dialogue related to diversity and inclusion } \\
\text { in the classroom. }\end{array}$ & & & & & \\
\hline
\end{tabular}

\begin{tabular}{|l|l|l|l|l|}
\hline $\begin{array}{l}\text { How useful did you find each of the following course } \\
\text { elements in enhancing your knowledge and understanding } \\
\text { of inclusivity and diversity in the classroom: }\end{array}$ & $\begin{array}{l}\text { Very } \\
\text { useful }\end{array}$ & Useful & $\begin{array}{l}\text { Somewhat } \\
\text { useful }\end{array}$ & $\begin{array}{l}\text { Not at } \\
\text { all } \\
\text { useful }\end{array}$ \\
\hline Readings & & & & \\
\hline Videos & & & & \\
\hline Discussion boards & & & & \\
\hline In-person discussions & & & & \\
\hline $\begin{array}{l}\text { Activities (e.g. Privilege Exercise, Implicit Associations } \\
\text { Test) }\end{array}$ & & & & \\
\hline Xavier data (e.g. Climate Survey, Student Mobility Data) & & & & \\
\hline Xavier documents (e.g. Seeking Integration and Wisdom) & & & & \\
\hline Optional resources included in each Module & & & & \\
\hline Daily Examen included in each Module & & & & \\
\hline
\end{tabular}




\begin{tabular}{|l|l|l|l|l|l|}
\hline $\begin{array}{l}\text { Check the appropriate box to indicate the } \\
\text { extent to which you agree or disagree with } \\
\text { each of the following statements: }\end{array}$ & $\begin{array}{c}\text { Strongly } \\
\text { agree }\end{array}$ & $\begin{array}{c}\text { Somewhat } \\
\text { agree }\end{array}$ & $\begin{array}{c}\text { Neither } \\
\text { agree } \\
\text { nor } \\
\text { disagree }\end{array}$ & disagree & $\begin{array}{c}\text { Strongly } \\
\text { disagree }\end{array}$ \\
\hline $\begin{array}{l}\text { The readings represented diverse } \\
\text { perspectives. }\end{array}$ & & & & & \\
\hline The amount of reading was reasonable. & & & & \\
\hline $\begin{array}{l}\text { The time required to complete the Academy } \\
\text { was reasonable. }\end{array}$ & & & & & \\
\hline $\begin{array}{l}\text { The variety of materials (readings, } \\
\text { discussion boards, videos, data) was useful. }\end{array}$ & & & & & \\
\hline Discussion board topics were engaging. & & & & \\
\hline $\begin{array}{l}\text { The Diversity and Inclusion Teaching } \\
\text { Academy challenged my previously held } \\
\text { assumptions about inclusivity and diversity } \\
\text { in the classroom. }\end{array}$ & & & & & \\
\hline $\begin{array}{l}\text { Overall the Diversity and Inclusion } \\
\text { Teaching Academy strengthened my } \\
\text { knowledge about inclusivity and diversity in } \\
\text { the classroom. }\end{array}$ & & & & & \\
\hline $\begin{array}{l}\text { The Diversity and Inclusion Teaching } \\
\text { Academy has provided me with specific } \\
\text { strategies for addressing inequality in the } \\
\text { classroom. }\end{array}$ & & & & & \\
\hline $\begin{array}{l}\text { Overall the Diversity and Inclusion } \\
\text { Teaching Academy has been worth the time } \\
\text { and effort I have invested. }\end{array}$ & & & & & \\
\hline
\end{tabular}

What do you see as the major strengths of the Academy? Were there specific readings, topics, or discussions that were especially useful?

How could the Academy be improved? Be as specific as possible.

What steps do you plan to take to foster greater inclusivity in your teaching as a result of participating in the Academy?

Additional comments: 